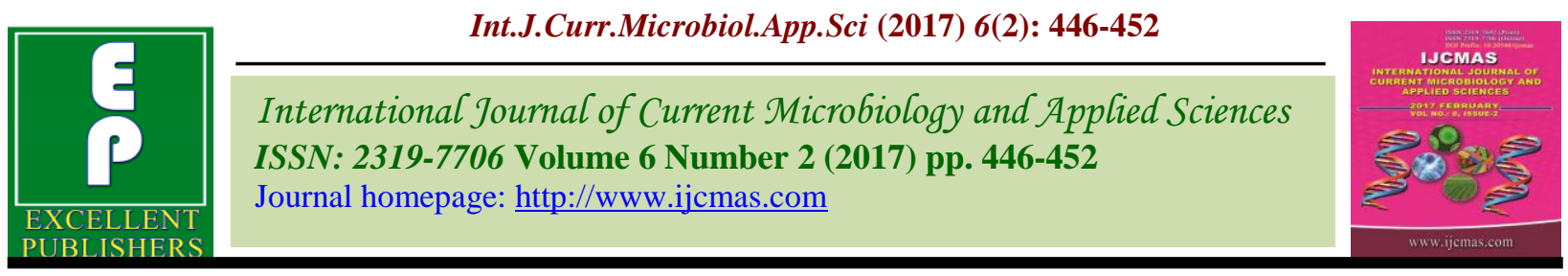

Original Research Article

http://dx.doi.org/10.20546/ijcmas.2017.602.050

\title{
Effect of Pesticide on the Suppression on the Growth and Development of Vigna mungo Treated with Rhizobium sp.
}

\author{
M. Indiradevi ${ }^{1 *}$, P. Madanraj ${ }^{1}$ and A. Panneerselvam ${ }^{2}$ \\ ${ }^{1}$ P.G and Research Department of Microbiology, Marudupandiyar College of \\ Arts and Science, Vallam, Thanjavur. \\ ${ }^{2}$ P.G and Research Department of Botany and Microbiology, A.V.V.M Sri Pushpam College \\ (Auto), Poondi, Thanjavur \\ *Corresponding author
}

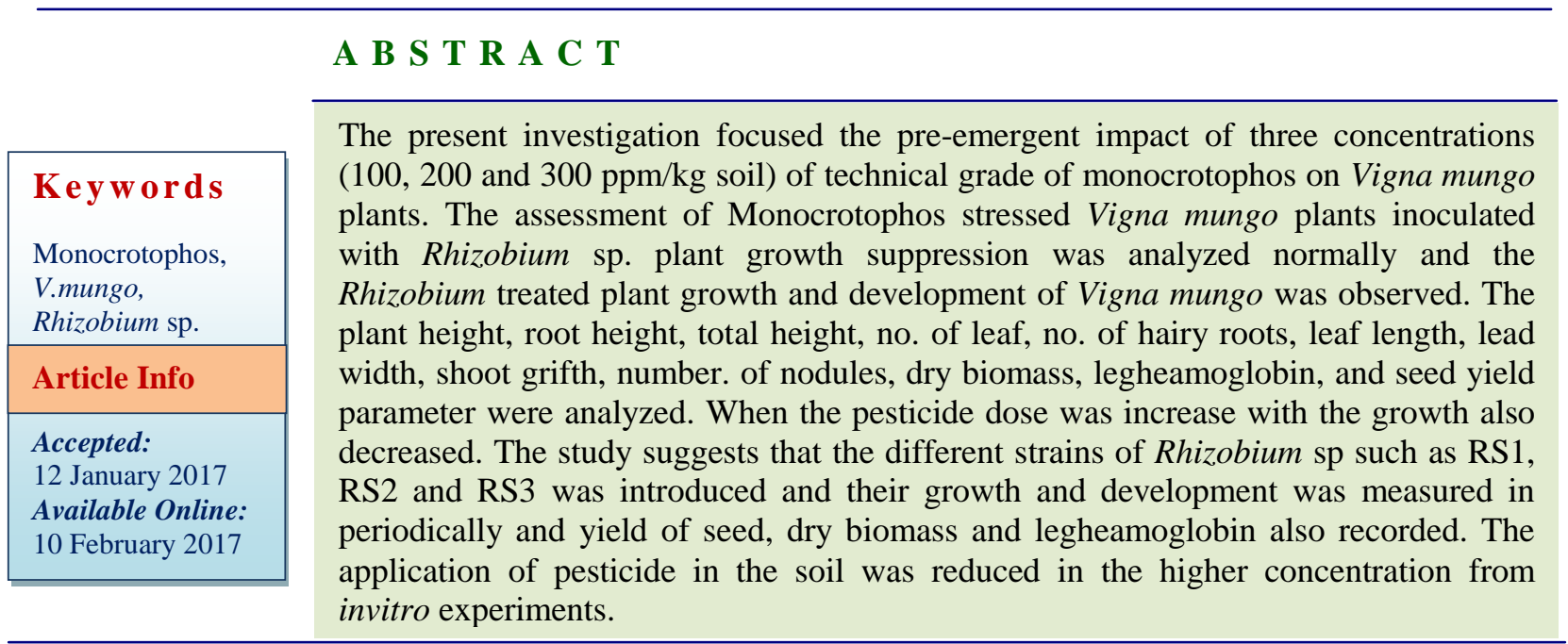

\section{Introduction}

Nitrogen is one of the most significant and essential element required for all life processes including plant. It is a component present in all amino acids, and is incorporated into proteins. Nitrogen is present in the base that makes up nucleic acids such as DNA and RNA in plants, (Smil, 2000). Nitrogen is a nutrient that is most commonly deficient in soils, contributing to reduced agricultural yields throughout the world. Nitrogen can be supplied to crops by biological nitrogen fixation (BNF), a process which is becoming more important for not only reducing energy costs, but also in seeking more sustainable agricultural production. Nitrogen fixing micro-organisms could therefore be an important component of sustainable agricultural systems.

Soil microorganisms contribute significantly to the maintenance of soil health by controlling the decomposition of plant and animal residues and participate of biogeochemical cycling, as nitrogen cycle. In the nitrogen cycle, biological nitrogen fixation has an important contribution. The nitrogen cycle is a biogeochemical essential process that converts different forms of 
nitrogen compounds that can be utilized for life processes. This transformation can be carried out via both biological and non biological processes. Important processes in the nitrogen cycle include fixation, mineralization, nitrification and denitrification (Odame, 1997).

Pesticides are widely used against a range of pests infesting agricultural crops. Globally, about $3 \times 10^{9} \mathrm{~kg}$ of pesticides is applied annually with a purchase price of nearly $\$ 40$ billion each year (Pan, 2003). The applied pesticides may harm the indigenous microorganisms, disturb soil ecosystem, and thus, may affect human health by entering in the food chain. Soil contains many types of microorganisms such as bacteria, actinomycetes, fungi, and algae, which are important because they affect the physical, chemical and biological properties of soil. Amongst the soil bacteria Rhizobium and Azotobacter have a beneficial effect on the growth of plants.

Pesticide use is effective for the protection of plants from pest (Johnsen et al., 2001), but the extensive use of pesticide over the past four decades has resulted in the disturbance of natural biological system (Bolognesi, 2003). Some pesticides used in agriculture can be harmful to nitrogen fixing bacteria, not only to inhibit the nitrogen fixation process in bacteria but also to reduce the bacterium respiration rate and hence preclude its positive effects (Tate, 1995; San Tos and Flores, 1995).

\section{Materials and Methods}

\section{Sample collection}

The experiment was performed in green house. Vigna mungo was selected as test plant, the Monocrotophos as a test pesticide and the Rhizobium was selected as the nitrogen fixing test bacteria.
Influence of pesticide on the growth inhibition of $V$. mungo treated with Rhizobium sp

The seeds of black gram (Vigna mungo) procured from TNAU, Kattuthottam, Thanjavur. The seeds were surface sterilized with $\mathrm{NaOCl}$ (Koenning and Barker, 1985) for 10 minutes and then rinsed three times with sterile water. The seeds were treated with Rhizobium strain and sown in steam sterilized soil mixture of 3:1 ratio (soil: sand) with different concentration of $(100,200$ and 300 ppm) pesticide treated soil in clay pots. The control pot served as sterilized soil with Rhizobium strain treated only. 30 and 60 days seedlings were transplanted as three seedlings per pot to calculate the morphometric and yield parameters individually in each pot. The experiment was terminated 90 days after inoculation and different parameters were determined.

\section{Leghaemoglobin content}

The leghaemoglobin content, in fresh nodules was estimated following the method described by Sadasivam and Manickam (1992). The reading was taken at 539 and $556 \mathrm{~nm}$ on spectrophotometer, against a reagent blank.

Lb concentration $(\mathrm{mM})=\frac{A 556-A 539}{23.4} \times 2 \mathrm{D}$

$\mathrm{D}=$ Initial dilution

Protein content

The seed and leaf protein content was estimated by adopting the methodology of Lowry et al., (1951). $50 \mathrm{mg}$ of oven dried black gram seeds and leaves were ground with the addition of $1 \mathrm{ml}$ of $5 \%$ trichloroacetic acid. The absorbance was read at $660 \mathrm{~nm}$ using spectrophotometer. The total protein content was calculated by comparing the absorbance of each sample with a 
calibration curve plotted by taking known graded concentration of bovine serum albumin.

\section{Results and Discussion}

The pesticide used (carbendazim thiram and imazethapyr) in recommended field doses appeared phytotoxic to the plants grown. Plants which were treated as the control in the performed experiment and were not treated with the fungicide and herbicide which was characterized by a considerably stronger growth and more abundant green matter as evidenced by the weight of the fresh matter of green parts. In addition the control plants were characterized by a very well developed root system. The strain in the control cultures (without pesticides) induced larger and more numerous nodules, while in the case of plants treated with the fungicide and herbicide the nodules by the strains were smaller and not as numerous which appears to confirm the effect of the chemicals of bacteria strain tested. In addition the reduced nodulation effects may be attributed to the carbendazim and imazetapir effect resulting in the inhibition of the lateral root growth in clover, Lucerne and serradella (Niewiadomska and Klama, 2005 and Uma Maheswari et al., 2016).

In the present study three different isolates of Rhizobium sp were treated with soil of Vigna mungo. In vitro studies were conducted. The RSI strain of Rhizobium sp was measured in the morphometric analysis. The soil sample with $100,200,300 \mathrm{ppm} / \mathrm{Kg}$ was treated in a trail field experiment conducted.

The RSI strain of Rhizobium treated V.mungo morphometric variation was $11.1 \mathrm{~cm}, 7.2 \mathrm{~cm}$, $18.3 \mathrm{~cm}, 13$ numbers, $15 \mathrm{~cm}, 2.0 \mathrm{~cm}, 0.9 \mathrm{~cm}$, $0.9 \mathrm{~cm}$ and 790 numbers of nodule with shoot height, root height, total height, width, Shoot grifth and number of nodules were recorded with $200 \mathrm{ppm}$ pesticide treated. The RS2 strain of Rhizobium was treated with $200 \mathrm{ppm}$ was high when compared to 100 and $300 \mathrm{ppm}$ concentration of pesticides treated. It was $11.1 \mathrm{~cm}, 4.5 \mathrm{~cm}, 15.6 \mathrm{~cm}, 15$ numbers of leaf $10 \mathrm{~cm}, 1.5 \mathrm{~cm}, 0.5 \mathrm{~cm}, 0.6 \mathrm{~cm}, 12$ numbers of nodules with above mentioned morphometric parameters were measured whereas in the case of RS3 strain treated with pesticide of $200 \mathrm{ppm}$ has higher growth whereas 100, and $300 \mathrm{ppm}$ with lesser growth was measured. But all the control pots of morphometric measures was high because nitrogen fixer Rhizobium sp was treated after 30 days of growth (Table 1).

Roopa et al., (2012) evaluated the effectiveness of PGPR and Rhizobium on nodulation and growth productivity in chickpea. Misra and Gaur (1974), in their investigations on the toxic herbicide effect on the plant, found that simazin used in peanut crops severely affected the nodulation of roots with concentration as low as $2 \mathrm{ppm}$. The dosage of the herbicide even in normal filed concentrations causes growth limitation, yellowing of the plants and their atrophy.

In the present study, the growth of 60 days control was observed high when compared with pesticide treated soil RS1 strain treated Vigna mungo. The control (Rhizobium treated) was $18.7 \mathrm{~cm}$, shoot height, $13.5 \mathrm{~cm}$ root height, $31.2 \mathrm{~cm}$ total height, $31.2 \mathrm{~cm}$ total height, 21 leaf, 48 number of hairy roots, $3.9 \mathrm{~cm}$ leaf length, $4.1 \mathrm{~cm}$ leaf width, $1.5 \mathrm{~cm}$ shoot grifth and 61 number of nodules was measured from the RS1 Rhizobium treated whereas RS2 strain treated was $13.5 \mathrm{~cm}, 9.2$ $\mathrm{cm}, 20.5 \mathrm{~cm}, 21$ numbers, 42 numbers, 2.2 $\mathrm{cm}, 1.5 \mathrm{~cm}, 1.9 \mathrm{~cm}, 43$ number of nodules produced in excellent growth of Vigna mungo with shoot height, root height, total height, number of leaf, number of hairy roots, leaf length, leaf width, shoot grifth, and number of nodules were recorded respectively (Table 2 ). 
Table.1 Effect of different strain of Rhizobium sp on the growth of Vigna mungo treated with different concentration of monocrotophos on 30th day

\begin{tabular}{|c|c|c|c|c|c|c|c|c|c|c|c|}
\hline S.No & $\begin{array}{l}\text { Rhizobium } \\
\text { strain }\end{array}$ & $\begin{array}{l}\text { Monocrotophos } \\
(\mathrm{ppm} / \mathrm{kg})\end{array}$ & $\begin{array}{l}\text { Shoot } \\
\text { height } \\
\text { (cm) }\end{array}$ & $\begin{array}{l}\text { Root } \\
\text { height } \\
\text { (cm) }\end{array}$ & $\begin{array}{l}\text { Total } \\
\text { height } \\
\text { (cm) }\end{array}$ & $\begin{array}{l}\text { No. of } \\
\text { leaf } \\
\text { (Nos) }\end{array}$ & $\begin{array}{ll}\text { No } & \text { of } \\
\text { hairy } & \\
\text { roots } & \\
\text { (Nos) } & \\
\end{array}$ & $\begin{array}{l}\text { Leaf } \\
\text { length } \\
\text { (cm) }\end{array}$ & $\begin{array}{l}\text { Leaf } \\
\text { width } \\
(\mathrm{cm})\end{array}$ & $\begin{array}{l}\text { Shoot } \\
\text { grifth } \\
(\mathbf{c m})\end{array}$ & $\begin{array}{l}\text { No of } \\
\text { nodules } \\
\text { (Nos) }\end{array}$ \\
\hline \multirow{4}{*}{1} & \multirow{4}{*}{ RS1 } & Control & 14.7 & 10 & 24.7 & 15 & 25 & 3.8 & 1.6 & 1.1 & 38 \\
\hline & & 100 & 8.5 & 5.5 & 14.0 & 10 & 12 & 2.1 & 1.1 & 0.9 & 21 \\
\hline & & 200 & 11.1 & 7.2 & 18.3 & 13 & 15 & 2.0 & 0.9 & 0.9 & 19 \\
\hline & & 300 & 6.1 & 4.2 & 10.3 & 11 & 13 & 1.4 & 0.5 & 0.5 & 12 \\
\hline \multirow{4}{*}{2} & \multirow{4}{*}{ RS2 } & Control & 12.5 & 12 & 24.5 & 16 & 28 & 2.9 & 1.2 & 1.3 & 29 \\
\hline & & 100 & 10.2 & 5.9 & 16.1 & 12 & 15 & 1.8 & 0.7 & 0.8 & 12 \\
\hline & & 200 & 11.1 & 4.5 & 15.6 & 15 & 10 & 1.5 & 0.5 & 0.6 & 12 \\
\hline & & 300 & 9.8 & 4.2 & 13.0 & 12 & 8 & 0.9 & 0.4 & 0.4 & 11 \\
\hline \multirow{4}{*}{3} & \multirow{4}{*}{ RS3 } & Control & 13.8 & 14.0 & 27.8 & 15 & 25 & 2.5 & 1.3 & 1.1 & 31 \\
\hline & & 100 & 11.2 & 6.1 & 17.3 & 12 & 16 & 1.5 & 0.6 & 0.9 & 12 \\
\hline & & 200 & 9.6 & 4.3 & 13.9 & 10 & 14 & 1.1 & 0.5 & 0.5 & 10 \\
\hline & & 300 & 8.1 & 3.9 & 12.0 & 8 & 9 & 0.9 & 0.1 & 0.2 & 6 \\
\hline
\end{tabular}

RS1-Rhizobium Strain 1, RS2- Rhizobium strain2, RS3- Rhizobium strain3 
Table.2 Effect of different strain of Rhizobium sp on the growth of Vigna mungo treated with different concentration of monocrotophos on 60th day

\begin{tabular}{|c|c|c|c|c|c|c|c|c|c|c|c|}
\hline $\begin{array}{l}\text { S. } \\
\text { No }\end{array}$ & Treatment & $\begin{array}{l}\text { Monocrotophos } \\
\text { (ppm) }\end{array}$ & $\begin{array}{l}\text { Shoot } \\
\text { height } \\
\text { (cm) }\end{array}$ & $\begin{array}{l}\text { Root } \\
\text { height } \\
\text { (cm) }\end{array}$ & $\begin{array}{l}\text { Total } \\
\text { height } \\
\text { (cm) }\end{array}$ & $\begin{array}{l}\text { No of } \\
\text { leaf } \\
(\text { Nos })\end{array}$ & $\begin{array}{ll}\text { No } & \text { of } \\
\text { hairy } & \\
\text { roots } & \\
\text { (cm) } & \end{array}$ & $\begin{array}{l}\text { Leaf } \\
\text { length } \\
(\mathrm{cm})\end{array}$ & $\begin{array}{l}\text { Leaf } \\
\text { width } \\
\text { (cm) }\end{array}$ & $\begin{array}{l}\text { Shoot } \\
\text { grifth } \\
\text { (cm) }\end{array}$ & $\begin{array}{l}\text { No of } \\
\text { nodules } \\
(\text { Nos) }\end{array}$ \\
\hline \multirow{4}{*}{1} & \multirow{4}{*}{ RS1 } & Control & 18.7 & 13.5 & 31.2 & 21 & 48 & 3.9 & 4.1 & 1.5 & 61 \\
\hline & & 100 & 15.1 & 10.2 & 25.3 & 19 & 36 & 3.1 & 2.9 & 1.1 & 52 \\
\hline & & 200 & 11.3 & 9.1 & 20.4 & 15 & 25 & 2.2 & 1.9 & 0.9 & 43 \\
\hline & & 300 & 9.6 & 5.2 & 14.8 & 14 & 19 & 1.9 & 0.8 & 0.8 & 41 \\
\hline \multirow{4}{*}{2} & \multirow{4}{*}{ RS2 } & Control & 19.7 & 10.3 & 30.0 & 25 & 56 & 4.1 & 3.5 & 1.5 & 67 \\
\hline & & 100 & 13.5 & 9.2 & 12.7 & 21 & 42 & 2.2 & 1.5 & 1.9 & 43 \\
\hline & & 200 & 12.2 & 8.3 & 20.5 & 16 & 30 & 1.5 & 0.7 & 1.2 & 32 \\
\hline & & 300 & 9.5 & 5.5 & 15.0 & 13 & 24 & 1.1 & 0.4 & 0.9 & 21 \\
\hline \multirow{4}{*}{3} & \multirow{4}{*}{ RS3 } & Control & 16.7 & 10.5 & 27.2 & 26 & 59 & 3.9 & 3.5 & 1.5 & 63 \\
\hline & & 100 & 11.9 & 5.5 & 17.4 & 16 & 29 & 1.3 & 0.4 & 0.9 & 27 \\
\hline & & 200 & 10.5 & 3.5 & 14.0 & 12 & 22 & 1.2 & 0.4 & 0.8 & 24 \\
\hline & & 300 & 9.1 & 4.5 & 13.6 & 10 & 21 & 1.1 & 0.3 & 0.8 & 19 \\
\hline
\end{tabular}

RS1-Rhizobium Strain 1, RS2- Rhizobium strain2, RS3- Rhizobium strain3 
Table.3 Effect of fungicide on Rhizobium tolerance with Black gram

\begin{tabular}{|c|c|c|c|c|c|c|}
\hline S.No & Treatment & $\begin{array}{l}\text { Monocrotophos } \\
\text { (ppm) }\end{array}$ & $\begin{array}{l}\text { Total dry } \\
\text { biomass } \\
\text { (g/plant) }\end{array}$ & $\begin{array}{l}\text { Leg } \\
\text { heamoglobin } \\
\text { (mg/g) }\end{array}$ & $\begin{array}{l}\text { Seed } \\
\text { yield } \\
\text { (g/plant) }\end{array}$ & $\begin{array}{l}\text { Grain } \\
\text { protein } \\
\text { (mg/g0 }\end{array}$ \\
\hline \multirow{4}{*}{1} & \multirow{4}{*}{ RS1 } & Control & 3.59 & 0.15 & 2.5 & 245 \\
\hline & & 100 & 3.01 & 0.09 & 1.1 & 205 \\
\hline & & 200 & 2.48 & 0.07 & 1.5 & 194 \\
\hline & & 300 & 1.97 & 0.05 & 1.0 & 185 \\
\hline \multirow{4}{*}{2} & \multirow{4}{*}{ RS2 } & Control & 4.32 & 0.16 & 3.7 & 273 \\
\hline & & 100 & 3.67 & 0.10 & 2.8 & 210 \\
\hline & & 200 & 3.01 & 0.08 & 2.4 & 204 \\
\hline & & 300 & 2.32 & 0.06 & 2.0 & 201 \\
\hline \multirow{4}{*}{3} & \multirow{4}{*}{ RS3 } & Control & 3.87 & 0.14 & 3.3 & 261 \\
\hline & & 100 & 2.83 & 0.09 & 1.4 & 205 \\
\hline & & 200 & 1.92 & 0.05 & 1.2 & 194 \\
\hline & & 300 & 1.54 & 0.03 & 1.0 & 151 \\
\hline
\end{tabular}

Niewiadomska (2004) observed a noxious influence of the applied pesticides (Funaben T, Pivot 100SL) on the nodulation root development and yield of Lucerne and clover by field and pot experimental condition. The effect of pesticide (monocrotophos) mixed with soil Rhizobium treated with Vigna mungo was high in the RS2 strain with total dry biomass leghemoglobin and seed yield was $4.328 / \mathrm{plant}, \quad 0.16 \mathrm{mg} / \mathrm{g}$ and $3.7 \mathrm{~g} / \mathrm{plant}$ observed when compared to RS1 and RS3 strain treated plants. Grain protein also 273 $\mathrm{mg} / \mathrm{g}$ was RS2 treated Vigna mungo was high content recorded respectively. However RS2 strain Rhizobium sp activity invitro and also able to perform significant growth was recorded (Table 3 ).

Nevertheless, in combinations in which plant protection compounds were used a lower percentage protein content was recorded in the plant dry matter in relation to the control treatments in which these preparations were not applied. This can be attributed among others to the reduced effectiveness of the process of nitrogen fixation caused by the action of pesticides. Some researchers reported that the decreased quantities of protein in plants could be attributed to the effect of plant protection agents on nitrogenase activity (Kao and Wang, 1986).

\section{References}

Johnsen, K., Jacobsen, C.S., Torsovik, V. and Sorensen, J. 2001. Pesticides effect on bacterial diversity in agriculture soilreview. Biol. Fertil. Soil, SpringerVerlag; 33:443-453.

Kao, T.C. and Wang, C.C. 1981. Studies on the effect of herbicides on growth of rhizobia and development of root nodules I effect of herbicides on the growth and development of legumes. Mem. Coll. Agric. Natl. Taiwan. Univ., 21: 9-15.

Koenning, S.R. and Barker, K.R. 1985. Gnotobiotic techniques for plant parasitic nematodes. An Advanced Treatise on Meloidogyne Vol II: Methodology. Publication of the Department of Plant Pathology and the USAID.

Lowry, O.H., Rosebrough, N.J., Farr, A.L. and Randall, R.J. 1951. Protein 
measurement with the Folin phenol reagent. J. Biol. Chem., 193: 265-275.

Niewiadomska, A. and Klama, J. 2005. Pesticides side effect on the symbiotic efficiency and nitrogenase activity of Rhizobiaxease bacteria family. Polish $J$. Microbiol., 54(1): 43-48.

Odame, H. 1997. Biofertilizers in Kenya Research production and extension dilemmas. Biotechnol. Dev. Monit., 30: 20-23.

Pan, U.K. 2003. Current pesticide spectrum, global use and major concerns.

Roopa, B., Maya, C. and Makari, H.K. 2012. Effect of different PGPR strains along with Rhizobium on nodulation and chickpea productivity. Asian J. Exp. Biol. Sci., 3: 424-426.

Sadasivam, S. and Manickam, A. 1992.
Biochemical Methods. (3rdedn), New Age International Publishers, New Delhi, India.

San-Tos, A. and Flores, M. 1995. Effects of glyphosate on nitrogen fixation of freeliving heterotrophic bacteria. Lett. Appl. Microbiol., 20: 349-352.

Smil, V. 2000. Cycles of Life. Scientific American Library, New York.

Tate, R.L. 1995. Soil Microbiology (Symbiotic Nitrogen Fixation. John Wiley \& Sons, New York: 307-333.

Uma Maheswari, N., Fathima Barjana, B. and Senthilkumar, R. 2016. Development of Herbicide Tolerant Rhizobium Species From Different Leguminous Plants. Int. J. Pure App. Biosci., 4(2): 245-249.

\section{How to cite this article:}

Indiradevi, M., P. Madanraj and Panneerselvam, A. 2017. Effect of Pesticide on the Suppression on the Growth and Development of Vigna mungo Treated with Rhizobium sp. Int.J.Curr.Microbiol.App.Sci. 6(2): 446-452. doi: http://dx.doi.org/10.20546/ijcmas.2017.602.050 